\title{
Measuring chain digitisation maturity: An assessment of Dutch retail branches
}

\author{
Marijn G.A. Plomp ${ }^{1,2}$ \& Ronald S. Batenburg ${ }^{1}$ \\ ${ }^{\mathbf{1}}$ Information and Computing Sciences, Utrecht University, Utrecht, The Netherlands \\ ${ }^{2}$ Dialogic Innovation and Interaction, Utrecht, The Netherlands
}

Published as: Plomp, M.G.A. \& Batenburg, R.S. (2010). Measuring chain digitisation maturity: An assessment of Dutch retail branches. Supply Chain Management: An International Journal, 15(3), 227-237.

\begin{abstract}
Purpose - The purpose of this article is to develop a validated measurement model and typology for chain digitisation maturity, defined as the degree of interorganisational collaboration through ICT.

Design/methodology/approach - Through a literature (meta) study, 22 existing maturity models are found and analysed, on the basis of which an integrated framework is developed. This framework is subsequently applied to interorganisational collaboration within the Dutch retail sector (i.e. retailers and their wholesalers, manufacturers, customers, and trade organisations). The measurement model is tested by determining the chain digitisation level of 24 different retail sub-sectors (branches) through desk research, interviews, and surveys. Data are collected at the level of the branch, mainly through representatives of trade organisations.
\end{abstract}

Findings - The framework (i.e. measurement model) appears to be applicable to describing the Dutch retail sector and comparing its branches, providing both expected and new insights. The typology supports the vision of the combination of two dimensions: the level of technology and the level of organisation.

Research limitations/implications - The framework has been applied to the (Dutch) retail sector only. It seems suitable for application to other sectors as well.

Practical implications - The empirical application provides an extended view of the current situation of the (Dutch) retail sector with regard to chain digitisation. On this basis, a roadmap can be derived to support the adoption and deployment of chain digitisation among retail organisations.

Originality/value - Our framework for chain digitisation and the derived typology are of value to the SCM research community, as they are specifically developed and tested at the level of interorganisational chains.

Keywords: Maturity model, Interorganisational information systems, Retail, SMEs, The Netherlands

Paper type: Research paper 


\section{Introduction}

The field of interorganisational information systems (IOIS) has a long history (e.g. Barrett and Konsynski, 1982) and many different terms to describe it have been introduced. Most prominently supply chain management (SCM) related terms such as supply chain automation, supply chain integration, and collaborative planning, forecasting, and replenishment (CPFR), but also more organisational/business related terms such as interorganisational collaboration, virtual organisations, and value networks or IT-related terms such as interoperability, ebusiness, and chain computerisation.

Trends like increasing competition, more demanding consumers, rising administrative burden, and a pending economic recession in many parts of the world make IOIS interesting for many organisations. The alleged advantages of IOIS seem to meet these challenges through cost reduction, productivity improvements, and innovation for competitive positioning (Barrett and Konsynski, 1982; Morrel and Ezingeard, 2002). There are many examples of (mainly large) organisations that have experienced significant improvements after altering their supply chain processes such as (the chains of) Dell, Wal-Mart, and Hewlett-Packard (Alvarado and Kotzab, 2001). A retail specific example is the study of Vieira et al. (2009), which looks at collaboration intensity in Brazilian large retail networks. It can be seen as an omission that there are fewer examples for smaller organisations. There seems to be no clear insight into which factors drive small businesses to adopt and deploy IOIS.

In this paper, we depart from the notion that without considering the organisational dimension, the deployment of technology (i.e. ICT) will be less useful and/or effective (e.g. Scott Morton, 1991; Daft, 2001; Turban et al., 2001; Luftman and Kempaiah, 2007). This is particularly the case for the success of interorganisational systems, including e-business (Zhu and Kraemer, 2002). The common notion is that technological and organisational systems reinforce each other, as evidenced for example by theory on business-IT alignment (Henderson and Venkatraman, 1993). At every scale and level, technology and management (or 'organisation') should be related.

Literature discussing the level of chain digitisation often focuses on one single organisation. As chain digitisation exceeds the level of a single organisation, its maturity actually should be measured at the chain level as well. Here, there seems to be a white spot. McCormack et al. (2008) stressed the importance of maturity models that take into account the wider context of the supply chain and also indicated that such a model does not yet exist. In this paper, we develop such a framework and validate the resulting measurement model at the level of interorganisational chains within a number of branches (i.e. sub-sectors of an industry).

Finally, it should be noted that we specifically use the term chain digitisation instead of IOIS to stress that it encompasses collaboration between multiple organisations, i.e. firms working together along value/supply chains through ICT. Chain digitisation is therefore to be interpreted as a broad concept. While some scholars make a distinction between the supply and demand side of chain management or automation, from a chain digitisation perspective this distinction is not or less relevant.

Given the above, we address three questions in this paper:

1. First, we set the question of how to measure the degree of chain digitisation at the level of interorganisational chains, recognising both the technological and organisational dimension? 
2. Second, we address the question of how to model alignment for chain digitisation (at the level of interorganisational chains)?

3. Question one and two build upon each other, for if we want to be able to say anything about the alignment, we need to actually distinguish different degrees of chain digitisation. We argue that policies to improve alignment at the level of interorganisational chains require a yardstick to actually determine the degree of chain digitisation. This leads up to our third and final research question: how to validate this model empirically in the context of the Dutch retail sector?

The structure of this article is as follows. First a meta-analysis (literature study) is presented which leads to an overview of existing models. Based on this, an integrated framework for measuring chain digitisation is developed, including a typology to classify interorganisational chains in this respect. Both the measurement model and typology are applied to a number of branches within the Dutch retail sector. At the end of the paper, limitations of this work are discussed, and to conclude, suggestions for future research endeavours are given.

\section{Meta-analysis: existing models}

Our search for academic models for measuring chain digitisation started by focusing on what can be labelled maturity models or lifecycle models. Models that were selected as relevant are models for interorganisational collaboration, preferably those mentioning ICT. Hence models that describe the development process or 'transformation' of interorganisational systems (e.g. strategy formulation, identification of opportunities, system design, etc.) were left out of the scope. We also focused on models that explicitly present different and defined levels or stages of deployment. Furthermore, only scientific publications (i.e. books, articles, and conference proceedings) were included. We did not exclude specific types of publications, as in computer science books, conferences, and journals are considered to be of equal importance (Meyer et al., 2009).

The models referenced in this section were found through an online literature search. Two search engines were used in this undertaking: Google Scholar and Omega. Google Scholar is a 'general purpose' academic-oriented search engine, which provides the user with selected scientific articles. Not much research has been done on this relatively new and public search engine, but a study by Jacsó (2008) evaluates the strengths and weaknesses of Scholar. A positive aspect is that it covers many scientific journals and books. The main downsides of Scholar mentioned by Jacsó are erroneous counting of results and problems in automatically distinguishing author names from the rest of the text. These shortcomings do not seem to affect our current purposes. Our second literature search engine was Omega, the name given to the online content search engine of Utrecht University. Omega covers over 16 billion fulltext papers from thousands of digital journals of different disciplines. Publishers included are Ebsco, Elsevier Science Direct, JStor, SpringerLink, IoP, ArXiv, Karger, Pubmed Central, Oxford Journals, and Highwire.

A total of 12 different queries (18 when English/American language differences were accounted for) were used with the keyword combination: "maturity" OR "model" AND

- "chain digiti[z|s]ation",

- "chain computeri[z|s]ation",

- "interorgani[z|s]ational cooperation", 
- "interorgani[z|s]ational collaboration",

- "interorgani[z|s]ational information systems",

- "IOIS",

- "IOS",

- "supply chain",

- "SCM",

- "value chain",

- "organi[z|s]ational network",

- "business network".

The online literature search provided many hits (i.e. literature sources found), but only a few publications fit our scope. At first, a total of 413,588 hits was found, 55 through Omega and 413,533 through Google Scholar. Note that these numbers are likely to include duplicates, both between and within search engines. While the limited number of search results from Omega can be considered as key findings, Google Scholar added many publications that were not included in the databases of university libraries and academic publishers. In terms of triangulation, we therefore believe that it is useful to use multiple search engines. Furthermore, the number of hits differed greatly between search terms, ranging from 6 for "chain digitisation" to 179,038 for "IOS".

We applied a stepwise method in performing the literature study. Based on the assumption that search engines tend to list the most relevant results first, only the first 100 were analysed. Subsequently, a second query was performed, where the search term was combined with the term "maturity model" to further limit the result set. This was done in order to double-check for possibly relevant items that were not discovered in the first 100 results. If this again yielded more than 100 results, these were also analysed, and subsequently limited by another query: the search term combined with "maturity model" (this time as a connected phrase, e.g. "SCM maturity model"). This never led to more than 100 results for a search term.

Our analysis of the search results consisted of checking the title and abstract (if available) of the source and scanning the publication for a maturity model (table, chart, or list of items). When after careful reading a 'unique' maturity model for chain digitisation was found (i.e. one that met our focus criteria and was developed by the original author or authors), it was included in our selection. Table 1 presents a schematic overview of the 22 models that were found and selected through this literature study process.

Comparing the list of 22 models reveals several differences. The main differences found are related to their degree of documentation, number of levels, scope, domain focus, and cumulativeness. These characteristics of the models are highly important, because they provide a specific perspective on the domain of chain digitisation maturity. As we will elaborate below, this table enables us to determine several common denominators for developing our integrated chain digitisation maturity model. 
Table 1 Overview of models of chain digitisation and their levels

\begin{tabular}{|c|c|c|c|c|c|c|c|c|c|}
\hline Name & Author(s) & Year & Source & Level 1 & Level 2 & Level 3 & Level 4 & Level 5 & Level 6 \\
\hline $\begin{array}{l}\text { Levels of information } \\
\text { sharing between } \\
\text { organisations }\end{array}$ & $\begin{array}{l}\text { Seidmann } \\
\text { and } \\
\text { Sundararajan }\end{array}$ & 1998 & $\begin{array}{l}\text { Book } \\
\text { (chapter) }\end{array}$ & $\begin{array}{l}\text { Ordering } \\
\text { information }\end{array}$ & $\begin{array}{l}\text { Operational } \\
\text { information }\end{array}$ & $\begin{array}{l}\text { Strategic } \\
\text { information }\end{array}$ & $\begin{array}{l}\text { Strategic and } \\
\text { competitive } \\
\text { information }\end{array}$ & & \\
\hline $\begin{array}{l}\text { Levels of supply chain } \\
\text { integration }\end{array}$ & Tyndall et al. & 1998 & Book & $\begin{array}{l}\text { Open-market } \\
\text { negotiations }\end{array}$ & Cooperation & Coordination & Collaboration & & \\
\hline $\begin{array}{l}\text { Organisational } \\
\text { interoperability maturity } \\
\text { model }\end{array}$ & $\begin{array}{l}\text { Clark and } \\
\text { Jones }\end{array}$ & 1999 & Conference & Independent & Ad hoc & Collaborative & Combined & Unified & \\
\hline $\begin{array}{l}\text { Chain computerisation: } \\
\text { organisation profile }\end{array}$ & Grijpink & 1999 & Journal & Informal talks & $\begin{array}{l}\text { Formal } \\
\text { consultation }\end{array}$ & $\begin{array}{l}\text { Joint decision } \\
\text { making }\end{array}$ & $\begin{array}{l}\text { Ad hoc joint action } \\
\text { (chain projects) }\end{array}$ & $\begin{array}{l}\text { Common network } \\
\text { organisation }\end{array}$ & \\
\hline $\begin{array}{l}\text { E-business development } \\
\text { framework }\end{array}$ & $\begin{array}{l}\text { Poirier and } \\
\text { Bauer }\end{array}$ & 2000 & Book & $\begin{array}{l}\text { Internal supply } \\
\text { chain } \\
\text { optimisation }\end{array}$ & Network formation & $\begin{array}{l}\text { Value chain } \\
\text { constellation }\end{array}$ & $\begin{array}{l}\text { Full network } \\
\text { connectivity }\end{array}$ & & \\
\hline Arcs of integration & $\begin{array}{l}\text { Frohlich and } \\
\text { Westbrook }\end{array}$ & 2001 & Journal & Inward-facing & Periphery-facing & $\begin{array}{l}\text { Supplier- or } \\
\text { customer-facing }\end{array}$ & Outward-facing & & \\
\hline $\begin{array}{l}\text { Evolution of enterprise } \\
\text { resource planning }\end{array}$ & $\begin{array}{l}\text { Kalakota and } \\
\text { Robinson }\end{array}$ & 2001 & Book & $\begin{array}{l}\text { Manufacturing } \\
\text { integration (MRP) }\end{array}$ & $\begin{array}{l}\text { Enterprise } \\
\text { integration (ERP) }\end{array}$ & $\begin{array}{l}\text { Customer-centric } \\
\text { integration (CRP) }\end{array}$ & $\begin{array}{l}\text { Inter-enterprise } \\
\text { integration (XRP) }\end{array}$ & & \\
\hline $\begin{array}{l}\text { Interorganisational } \\
\text { information systems } \\
\text { types }\end{array}$ & Shah et al. & 2002 & Journal & $\begin{array}{l}\text { No electronic } \\
\text { integration }\end{array}$ & Low integration & $\begin{array}{l}\text { Moderate } \\
\text { integration }\end{array}$ & High integration & & \\
\hline $\begin{array}{l}\text { Stages of growth for e- } \\
\text { business (SOGe) model }\end{array}$ & $\begin{array}{l}\text { Prananto et } \\
\text { al. }\end{array}$ & 2003 & Conference & $\begin{array}{l}\text { No clear direction } \\
\text { for the } \\
\text { organisation's e- } \\
\text { business } \\
\text { initiatives }\end{array}$ & $\begin{array}{l}\text { E-business } \\
\text { initiatives are } \\
\text { increasingly } \\
\text { considered as an } \\
\text { important } \\
\text { component of the } \\
\text { organisation's } \\
\text { business }\end{array}$ & $\begin{array}{l}\text { Clear direction for } \\
\text { e-business } \\
\text { initiatives } \\
\text { development, but } \\
\text { still technology- } \\
\text { centric }\end{array}$ & $\begin{array}{l}\text { E-business } \\
\text { adoption and } \\
\text { development is } \\
\text { becoming more } \\
\text { business-focused }\end{array}$ & $\begin{array}{l}\text { E-business } \\
\text { initiatives aim to } \\
\text { provide strategic } \\
\text { benefits by } \\
\text { building strategic } \\
\text { systems }\end{array}$ & $\begin{array}{l}\text { E-business is } \\
\text { deeply embedded } \\
\text { throughout every } \\
\text { aspect of the } \\
\text { organisation; } \\
\text { strong integration }\end{array}$ \\
\hline $\begin{array}{l}\text { Levels of collaborative } \\
\text { planning, forecasting, } \\
\text { and replenishment } \\
\text { (CPFR) }\end{array}$ & $\begin{array}{l}\text { Skjoett- } \\
\text { Larsen et al. }\end{array}$ & 2003 & Journal & Basic CPFR & Developing CPFR & Advanced CPFR & & & \\
\hline $\begin{array}{l}\text { Types of supply chain } \\
\text { evolution }\end{array}$ & Folinas et al. & 2004 & Journal & $\begin{array}{l}\text { Core logistics } \\
\text { activities' } \\
\text { efficiency }\end{array}$ & $\begin{array}{l}\text { Coordination of } \\
\text { internal } \\
\text { organisational } \\
\text { processes }\end{array}$ & $\begin{array}{l}\text { Inter-enterprise } \\
\text { business } \\
\text { exchanges }\end{array}$ & $\begin{array}{l}\text { Establishment of } \\
\text { dynamic networks } \\
\text { between virtual } \\
\text { organisations }\end{array}$ & & \\
\hline
\end{tabular}




\begin{tabular}{|c|c|c|c|c|c|c|c|c|c|}
\hline Name & Author(s) & Year & Source & Level 1 & Level 2 & Level 3 & Level 4 & Level 5 & Level 6 \\
\hline $\begin{array}{l}\text { Supply chain redesign } \\
\text { capability maturity } \\
\text { model }\end{array}$ & $\begin{array}{l}\text { Handfield } \\
\text { and Straight }\end{array}$ & 2004 & Conference & Basic beginnings & $\begin{array}{l}\text { Moderate } \\
\text { development }\end{array}$ & $\begin{array}{l}\text { Limited } \\
\text { integration }\end{array}$ & $\begin{array}{l}\text { Fully integrated } \\
\text { supply chains }\end{array}$ & & \\
\hline $\begin{array}{l}\text { Business process } \\
\text { orientation maturity } \\
\text { model }\end{array}$ & $\begin{array}{l}\text { Lockamy and } \\
\text { McCormack }\end{array}$ & 2004 & Journal & Ad hoc & Defined & Linked & Integrated & Extended & \\
\hline $\begin{array}{l}\text { Levels of information } \\
\text { technology adoption }\end{array}$ & Wang et al. & 2004 & Journal & $\begin{array}{l}\text { Essential } \\
\text { functions }\end{array}$ & $\begin{array}{l}\text { Single department } \\
\text { / operation } \\
\text { process }\end{array}$ & $\begin{array}{l}\text { Cross department } \\
\text { / multi-process } \\
\text { integration }\end{array}$ & $\begin{array}{l}\text { Enterprise } \\
\text { integration } \\
\text { process }\end{array}$ & $\begin{array}{l}\text { B2B integration / } \\
\text { collaborative } \\
\text { business }\end{array}$ & \\
\hline Collaboration continuum & $\begin{array}{l}\text { McDougall et } \\
\text { al. }\end{array}$ & 2005 & Conference & Cooperation & $\begin{array}{l}\text { Mutual } \\
\text { adjustment }\end{array}$ & Alliance & $\begin{array}{l}\text { Corporate } \\
\text { partnerships }\end{array}$ & & \\
\hline $\begin{array}{l}\text { Levels of supply chain } \\
\text { integration }\end{array}$ & McLaren & 2006 & Conference & Functional focus & $\begin{array}{l}\text { Internal } \\
\text { integration }\end{array}$ & Linked network & $\begin{array}{l}\text { Integrated } \\
\text { network }\end{array}$ & $\begin{array}{l}\text { Optimised } \\
\text { network }\end{array}$ & \\
\hline $\begin{array}{l}\text { Development phases of } \\
\text { ICT use }\end{array}$ & $\begin{array}{l}\text { Statistics } \\
\text { Netherlands }\end{array}$ & 2006 & $\begin{array}{l}\text { Statistical } \\
\text { report }\end{array}$ & $\begin{array}{l}\text { No external data } \\
\text { communication }\end{array}$ & $\begin{array}{l}\text { External data } \\
\text { communication; } \\
\text { no website, sales, } \\
\text { electronic product } \\
\text { delivery, or on- } \\
\text { line after-sales } \\
\text { service }\end{array}$ & Website & Electronic sales & $\begin{array}{l}\text { Electronic product } \\
\text { delivery and/or } \\
\text { after sales service }\end{array}$ & $\begin{array}{l}\text { Linking the } \\
\text { company's order } \\
\text { processing system } \\
\text { with that of } \\
\text { buyers/clients }\end{array}$ \\
\hline $\begin{array}{l}\text { Construction supply } \\
\text { chain maturity model } \\
\text { (CSCMM) }\end{array}$ & $\begin{array}{l}\text { Vaidyanathan } \\
\text { and Howell }\end{array}$ & 2007 & Conference & Ad-hoc & Defined & Managed & Controlled & & \\
\hline $\begin{array}{l}\text { Levels of inter- } \\
\text { organisational } \\
\text { information system } \\
\text { development }\end{array}$ & Williamson & 2007 & Journal & Elementary IOS & Intermediate IOS & Advanced IOS & & & \\
\hline $\begin{array}{l}\text { Stages of process } \\
\text { integration }\end{array}$ & Aryee et al. & 2008 & Journal & Optimisation & Integration & $\begin{array}{l}\text { Supply } \\
\text { synchronisation }\end{array}$ & $\begin{array}{l}\text { Demand } \\
\text { synchronisation }\end{array}$ & & \\
\hline $\begin{array}{l}\text { Supply chain } \\
\text { management maturity } \\
\text { model }\end{array}$ & Schoenfeldt & 2008 & Book & Siloed company & $\begin{array}{l}\text { Internal } \\
\text { integration }\end{array}$ & $\begin{array}{l}\text { One level of } \\
\text { integration / } \\
\text { partnership }\end{array}$ & $\begin{array}{l}\text { Two levels of } \\
\text { integration }\end{array}$ & $\begin{array}{l}\text { Entire chain } \\
\text { integration }\end{array}$ & \\
\hline $\begin{array}{l}\text { Maturity levels for } \\
\text { interoperability in digital } \\
\text { government }\end{array}$ & Gottschalk & 2009 & Journal & $\begin{array}{l}\text { Computer inter- } \\
\text { operability }\end{array}$ & $\begin{array}{l}\text { Process inter- } \\
\text { operability }\end{array}$ & $\begin{array}{l}\text { Knowledge inter- } \\
\text { operability }\end{array}$ & $\begin{array}{l}\text { Value inter- } \\
\text { operability }\end{array}$ & $\begin{array}{l}\text { Goal inter- } \\
\text { operability }\end{array}$ & \\
\hline
\end{tabular}


Not every chain digitisation model is documented to the same degree. Many models (10 out of 22) were presented in a paper published in an international peer-reviewed journal. Others were published in a book (5), conference paper (6), or statistical report (1). Also, the extent to which models are presented in the papers differs. Sometimes the model is the main topic of the publication (e.g. Folinas et al., 2004), whereas in other cases it is only a small part of the publication (e.g. Seidman and Sundararajan, 1998) or only a picture of the model is presented (e.g. Handfield and Straight, 2004).

With regard to the number of levels or stages, we found that most models (18 out of 22) have four or five levels. Two models consisted of six levels and two other models mentioned only three stages. It is notable that the labels of these latter models (i.e. Skjoett-Larsen et al., 2003; Williamson, 2007) are not very informative. Both have a 'basic-intermediate-advanced' way of naming their levels. Another finding is that different labels are used between models for what might be considered the 'same' maturity level. E.g. one could say that the level 'core logistics activities' efficiency' defined by Folinas et al. (2004) is similar to the level 'functional focus' as defined by the model of McLaren (2006). However, we do not aim to create a common standard here, to actually make this kind of mappings between the levels of all models. We therefore remain by comparing the models with regard to their number of levels, i.e. their 'range' or scope.

An interesting point concerning the scope is that most chain digitisation models encompass the entire chain (e.g. from producer to customer), but differ with respect to their focus on the single organisation or (a part of) a chain as the level of observation or measurement. This distinction between the organisational and chain level is quite basic in the field, as described for instance by Harland (1996). She distinguished four levels of SCM research: internal chain, dyadic relationship, external chain, and network. Each of the 22 models we found obviously has at least some form of chain orientation (i.e. moving beyond the level of the internal chain) - otherwise it would not have been included in the selection. Nevertheless, at least 8 of the models focus entirely on an individual organisation, whereas others do so for the first levels and direct their attention to the entire chain only at the higher levels of the model (e.g. Folinas et al., 2004). Only 3 models have a specific chain focus in that they depart not from the viewpoint of an individual focal organisation, but from the chain itself. We will return to this point when we discuss our own integrated framework.

Concerning the domain focus of the chain digitisation models, 11 models were found to concentrate on organisational aspects such as processes, governance, and product standardisation (e.g. Grijpink, 1999). Three models can be considered to be focused on the use of information technology (e.g. Statistics Netherlands, 2006). The remaining 8 models take both domains into account (e.g. Folinas et al., 2004).

A specific comparison can be made of the differences in cumulativeness of the models. In general, a specific trait of maturity models is that levels are assumed to be cumulative. That is, achieving level $x$ implies that level $x-1$ is also fulfilled. Capability Maturity Model based quality models, for instance, apply this principle to assessing or benchmarking firms or departments (Paulk et al., 1995). The general idea is that compliance with all 'lower' parts of the ladder is required as they are necessary conditions to achieve the higher ones; that is, no parts or (sub-)steps can be skipped. Some models do not comply with this (interestingly enough, largely unwritten) rule. At the lowest level they define an organisation as 'inwardfacing', while at level four it is labelled 'outward-facing'. It is not defined by the authors, however, that an outward-facing organisation probably still deals with internal matters adequately. Moreover, the authors of these models do not claim to comply with the 
accumulation assumption themselves. In only one model description (Statistics Netherlands, 2006) was it stated explicitly that the 'accumulation assumption' is not valid for this model. Also, only for one model (Grijpink, 1999) was it acknowledged that the model does adhere to the assumption. In general, however, all models do comply with the general notion of maturity models that each level is 'better' or 'higher' than the level that precedes it. It should be noted that the differences between levels cannot be explicated as the levels are mostly described in words instead of 'hard measurements'. Still, one should realise that all chain digitisation models define ordinal scales at most.

\section{Towards an integrated framework}

Based on the 22 models found and the subsequent analysis of these models in the previous section, we developed an integrated framework. This framework incorporates the contents of many models as well as our specific findings with respect to model scope, domain focus, and the number of levels.

From the finding that models focus on organisational or technological aspects or both, we argue that a combined model should take both dimensions into account. The recent stream of business-IT alignment theory and its validation (see Chan and Reich, 2007) provides a fundamental reason for the organisational and technological domain to coincide. In particular, with complex systems as interorganisational chains, the alignment of business and IT is crucial in order to achieve successful collaboration. This also implies that it requires actors at the chain level to coordinate this interorganisational business-IT alignment (a 'value chain orchestrator' for instance). From our literature analysis, however, it appeared that most models focus on measuring the activities or policies of a single organisation. This defines or measures the 'chain readiness' of an organisation, but if we want to analyse the degree of digitisation of the chain itself, however, we should define a model that addresses behaviour at the level of the chain accordingly.

Based on these starting points we delineate our framework for chain digitisation to model the alignment of the organisational and technological dimension, explicitly, at the chain level. In doing so, we first define the two dimensions separately to ensure that we cover each by its domain-specific developments and indicators. Then, we define the range of both dimensions as equally as possible by setting the 'minimum' and 'maximum', and subsequently divide this range into four levels that are also as equally divided as possible. Most models we found in our literature study consist of four levels. This seems a sensible amount, comprising one level for 'low' or 'no' chain digitisation, one for 'full' or 'complete', and two for the remaining intermediate levels between these. Because we want to assess alignment, we formulate both dimensions with the same number of levels.

\section{The technological dimension}

When we consider the chain digitisation models from our online literature study that have an explicit technological component, it stands out that their structures are quite similar. At the lower levels there are no or hardly any technologies that have linkages outside the organisation itself, whereas at the highest level of the models, extensive technological integration between parties is realised. The levels we define are similar to those defined by Folinas et al. (2004) and Statistics Netherlands (2006). These two chain digitisation models provide indicators to enable (indicative) measurements, and cover the broadest spectrum of the recent developments in IT from a chain perspective. 
For the technological dimension we distinguish four different levels that represent an increasing degree of chain digitisation:

1. No chain automation. There is no interorganisational technology. This means that at the level of the single organisation there is no use of ICT at all, there is island automation, or there are even many internal linkages (e.g. an Enterprise Resource Planning (ERP) system). Whichever is the case, there are no digital connections to the outside world.

2. E-business. At this level ICT is used to cross the borders of the organisation. Connections are made between for example the stock system of a retailer and the order system of a supplier. This is also called eXtended ERP (XRP), indicating that the internal information system extends outside the organisation itself (Kalakota and Robinson, 2001). In this phase, the focus lies on transactional processes.

3. E-collaboration. A type of ICT that serves collaboration between multiple parties in the chain. Standards and standardisation of product databases and descriptions are relevant here. E-collaboration comprises tactical processes.

4. Open, n-tier sourcing. A level that differs from the preceding level because the technology is available and used by all (' $n$ ') parties within and between value chains. Data come from multiple locations through open standards and architectures (Van Beers and Bouwman, 2007).

Earlier we referred to the accumulation assumption of maturity models, that is, when a certain level is achieved all lower levels need to be passed. Here, we do not follow this assumption as we believe that in our technological dimension for a specific level $x$, a technology may be required that actually obsoletes technology from level $x-1$. A good example is the recent replacement of Electronic Data Interchange (EDI) by eXtensible Markup Language (XML) technology (Zhu et al., 2006).

\section{The organisational dimension}

Just as with the technological dimension, almost all of the models we analysed in the literature study that relate to the organisational dimension have a similar structure. There is, however, diversity as to which organisational aspect is concerned, probably because 'organisation' is a broader concept. It is notable that many chain digitisation models focus on the extent of collaboration: internal, between some parties, or across the entire chain. The models of Wang et al. (2004) and Schoenfeldt (2008), for instance, assume that interorganisational collaboration is only relevant for the extended chains.

For the organisational dimension of chain digitisation we distinguish four different levels which cumulate along an ordinal scale:

1. No chain collaboration. There are no interorganisational relationships. Note that this says nothing about the internal organisation, which may be fully integrated or consist of separate parts.

2. Bilateral collaboration. In this case there is collaboration with another organisation, which can be in the same line of work (e.g. a retailer working together with another retailer), but is more often a connected link of the value chain (e.g. a retailer working together with its supplier). Think about the sharing of information such as turnover per 
product (which are the best-selling products?) and stock information (when do which items need to be replenished?).

3. Multilateral collaboration. This is in fact the same as the previous level, but with multiple parties. It can be in the form of collaborative planning, forecasting, and replenishment (CPFR) - the joint management of resources in the chain based on supply and demand information. A similar notion is collaborative commerce, where information in the chain is shared and even activities like product design are performed jointly (Turban et al., 2004).

4. Extended chain collaboration. At this level there is collaboration between multiple parties across multiple links within and between value chains. One of the many possibilities is a retailer who passes the product requirements of a consumer directly on to the producer. Another example is a consultative body for discussing problems or making arrangements that concern all actors in the chain. The interaction is truly many-to-many and ' $n$-tier', including the customers and suppliers of all chain organisations.

\section{Integration: a typology for chain digitisation}

Business-IT alignment implies that interorganisational chains benefit from a strong connection between the technological and organisational dimension as defined above. From this it can be assumed that interorganisational alignment is more successful if both dimensions are on the same maturity level. This can be called alignment by 'levelling' (cf. Batenburg and Versendaal, 2008), and can be seen as a precondition for the 'direct' alignment as defined by Henderson and Venkatraman (1993) and Luftman and Kempaiah (2007). Therefore we combine the two previously described dimensions into a single framework, that is a 4 by 4 matrix, within which different (integrated) chain digitisation situations can be defined. To maintain an overview, we distinguish the four situations or types, depicted in Figure 1 as the four quadrants of the matrix:

- Basic chain digitisation. Within this interorganisational chain, both collaboration and the available technology are at a low level. There is bilateral collaboration at best and technology is used for transactions only. Regarding their maturity, both dimensions are in balance, however. This can for instance be the case in interorganisational chains that encompass relatively standard and frequent processes and transactions, such as in markets for fast-moving consumer goods.

- Technological proficiency. Despite the fact that the interorganisational collaboration is still low, the available technology within this interorganisational chain is of a more sophisticated level (i.e. no less than at the point of e-collaboration). The two dimensions are not in balance. This can be the case if an interorganisational chain has standard, frequent transactions that require relatively low levels of trust between the parties. These can be e-auctions or e-marketplaces in industrial markets for raw materials and the logistics/transport sector.

- Relational proficiency. As the opposite of technological proficiency, within this interorganisational chain there is advanced collaboration (i.e. multilateral collaboration or more), but the technology lags behind with regard to the chain digitisation maturity. Again, there is no balance between the two dimensions. This could occur in interorganisational chains that deal with non-standard transactions that involve a high 
amount of trust and hence personal contact, such as in one-of-a-kind industry or project-based sectors like the construction industry.

- Advanced chain digitisation. Within this interorganisational chain, the available collaboration and the existing technology are both at the same, developed level. Hence, both dimensions are in alignment with each other. Interorganisational chains that concern products or services that have complex specifications but are nevertheless ordered with high or predictable frequency are examples of this type. Examples are the mature e-commerce industries such as travel agencies and multimedia consumer markets.

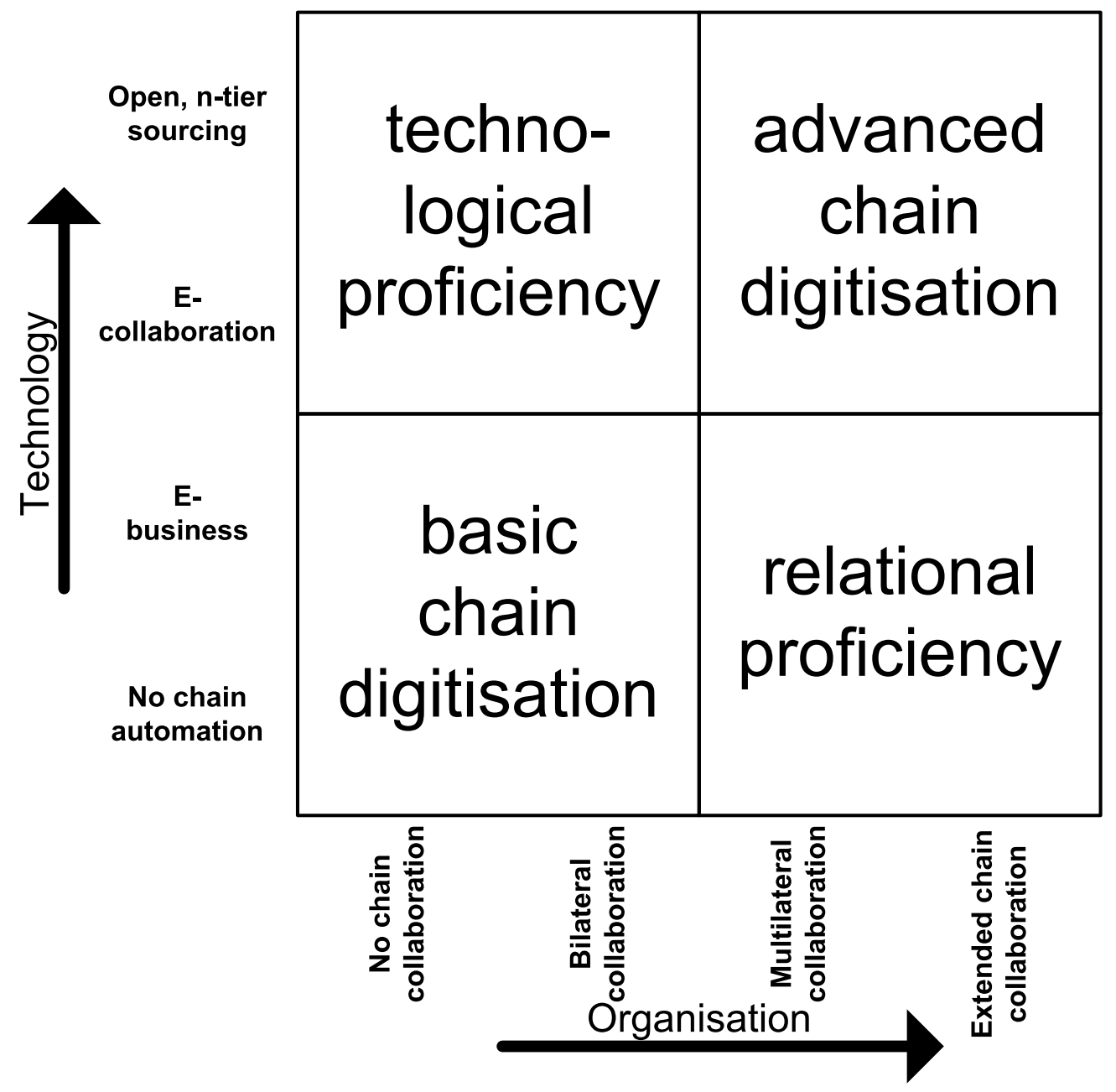

Figure 1 A typology for chain digitisation

Note that the above-mentioned types do not imply a sequential order of development. Although it is likely that an interorganisational chain will start at basic chain digitisation and through technological or relational proficiency develop towards advanced chain digitisation, it is also possible that direct development from the former to the latter occurs. The framework primarily indicates that there is considerably less chain digitisation at the first than there is at the last type, and that the other two types are in-between this. Also, it can be the case that interorganisational chains that are 'misaligned' are still successful in terms of their added 
value; likewise the chains that have both low technological and low organisational maturity might not need to grow to a higher maturity level because of their specific circumstances ('situationality').

\section{Empirical application: the Dutch retail sector}

To apply our framework in practice, field research within the Dutch retail sector was performed. First the motives for selecting this sector will be described. Subsequently the method will be presented, followed by the results.

\section{Motives}

The threats described in the introduction of this paper (competition, demanding customers, administrative burden, and economic recession) are very much the reality for the small and medium-sized enterprises (SMEs) that make up about $95 \%$ of the Dutch retail sector. A recent study by order of the European Commission (2008) shows that EU retailers tend to use less ebusiness compared to US retailers. Furthermore, SME retailers are behind larger companies with regard to ICT uptake. Earlier, other scholars studying Scottish (Wagner et al., 2003) and Norwegian companies (Vaaland and Heide, 2007) also found that SMEs generally lag behind their larger counterparts with respect to SCM. Vaaland and Heide call for more research on this topic, preferably focused on one sector and in other countries.

Logistics and supply chain management are the core business of the retail sector as they are mostly the last party in the chain (i.e. moving products from producer through wholesaler and retailer towards the end customer). This puts the retail sector in a specific chain position and makes it an interesting domain for chain digitisation. Finally, retail is concerned with trade, which is an important activity for the macro economy.

\section{Method}

Instead of querying retail organisations, we collected data at the level of trade organisations that represent a certain retail branch. As the retail sector is very diverse due to the nature of the traded products, this provides an interesting opportunity to explore differences by the type of retail branch. One can think of differences between food and non-food branches or supplyand demand-driven branches, as the logistics and specificity of the interorganisational chains differ greatly. Trade organisations were chosen because they represent many SME retailers and they commonly have knowledge of the important players in the interorganisational field (e.g. manufacturers, suppliers), regulations, and consumer trends. It should be acknowledged however, that only one actor has been queried per branch.

The population of Dutch branches was examined through desk research, interviews, and surveys. Data collection took place from November 2006 to June 2007. Desk research was performed for 35 different retail branches. In terms of 'size', branches varied with regard to the number of retailers, turnover and employment. This desk research consisted of collecting branch statistics, visiting the websites of trade organisations, and performing Google searches for the specific branches. Then 12 trade organisations of an equal number of retail branches were investigated through semi-structured face-to-face interviews with representatives of the trade organisations. The remaining trade organisations (23) were approached with a questionnaire through post and e-mail, which had a similar setup as the interview. 


\section{Results}

Of the 35 retail trade organisations, 24 took part in the research; a participation rate of $69 \%$. The 11 trade organisations which did not participate maintained their refusal after repeated requests by telephone. They brought up various reasons such as lack of time, interest in, and/or knowledge about the subject. Non-response analysis shows that it is unlikely that the non-response group of branches is biased, as it consists of traditional and modern, food and non-food, and small as well as large branches.

The scoring process used to classify branches onto the technological and organisational dimensions of our framework was based on combining several sources. Basically, the answers to the interview and survey questions were cross-validated with documents and other secondary sources. For instance, the application of the technological dimension was based on indicators as the advancement of purchase and ordering systems within the branch, and the existence of communication (ICT) standards for formatting, storing and exchanging retail product data. The organisational dimension was based on indicators as the existence of formal interorganisational bodies through which the supply chain partners communicate and collaborate on a regular basis, and specific organizational 'platforms' to enable and support chain digitisation within the branch. After the maturity scores for all retail branches were allocated and assigned in a comparative way, these were finally validated by the respondents and an expert on the Dutch retail sector. As some retail branches were quite diverse (for instance, some retailers have fully automated their external connections, while other still struggle with their internal shop automation), scoring them at one unified maturity level was complex. For this reason, in some cases an 'average' or a score between two levels was imputed.

Figure 2 shows the scores of the 24 retail branches, plotted on both the technological and the organisational dimension of chain digitisation. For the Dutch retail sector, it is found that in general the level of chain digitisation is low. This is in line with research in other countries and the expectations of the Dutch central industry board for retail trades. Most branches are of the 'limited chain digitisation' type. Nevertheless, 6 branches are positioned within the 'relational proficiency' type (see also Figure 2). 


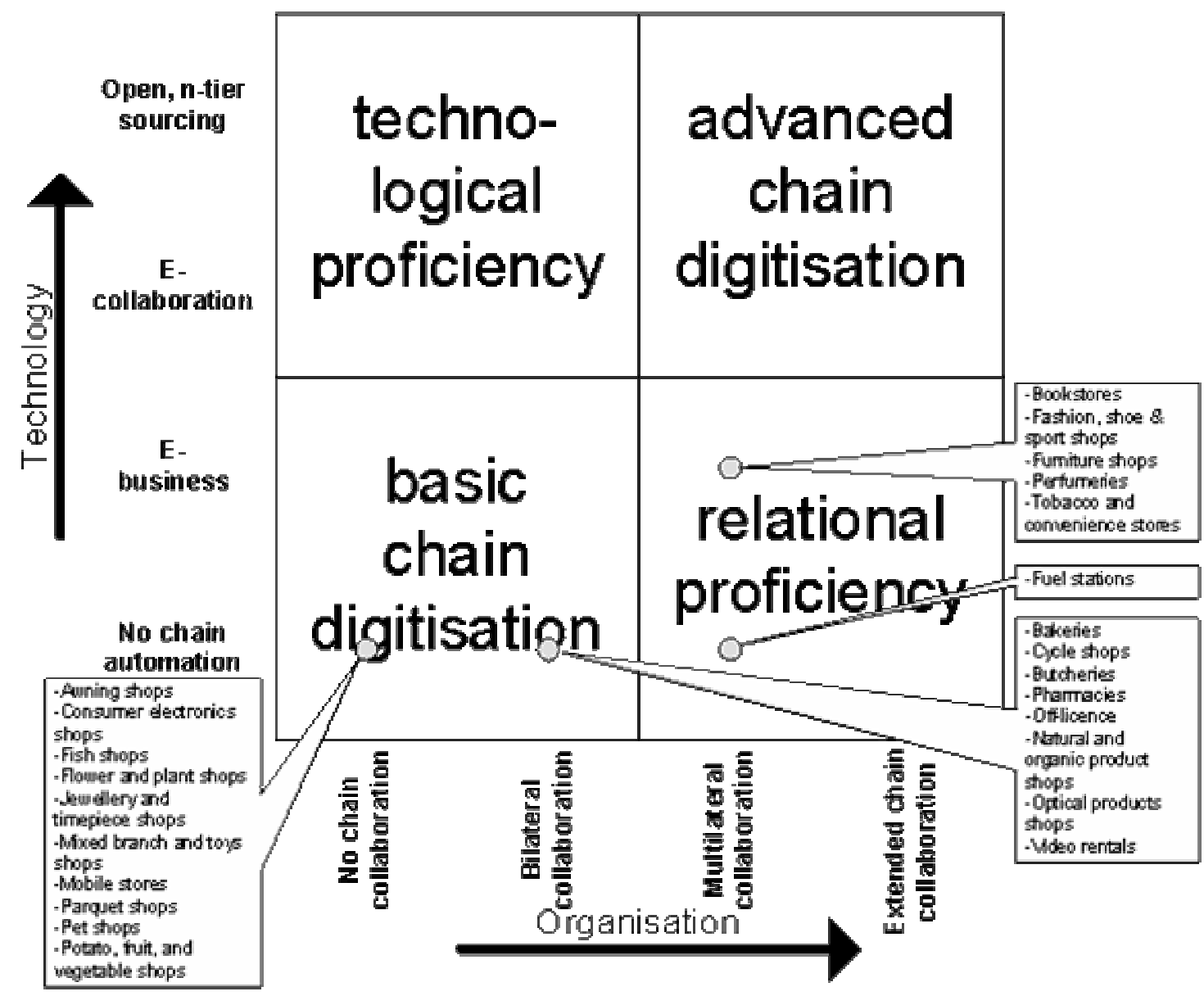

Figure 2 The 24 retail branches plotted in the typology

A first expectation that can be tested using these results concerns the difference between the food and non-food retail branches, as these deal with different types of products and related chain logistics. Food products, for instance, are more vulnerable to time and temperature fluctuations, putting more pressure on chain collaboration and information exchange throughout the chain (Kärkkäinen, 2003). From Figure 2 it appears however, that the food branches have lower maturity scores on both dimensions. Secondly, we tested the expectation that the supply-driven and demand-driven branches differ with regard to their levels of chain digitisation. Supply-driven retailers might be more mature because of supply chain pressure from their 'pushing' wholesale and manufacturing chain partners (cf. Daft, 2001). A difference between these two types of branches cannot be confirmed by the results, however. Hence, alternative explanations are needed to understand the systematic varieties we find in the chain digitisation scores of the branches. During our field work for instance, we experienced that some branches are more 'conservative' in interorganisational cooperation by culture or tradition. Also scale or size probably matters, in terms of chain length or product diversity. Specific indicators lack to explicitly test these alternative explanations however. Also, the number of observations (i.e. the number of branches included) draws upon empirical limitations to execute subsample comparisons. We return to this point in the discussion section. 


\section{Conclusion}

In sum, this paper presents a framework and a typology for chain digitisation at the level of interorganisational chains. The framework builds upon a meta study of existing maturity models of chain digitisation. In order to test its validity, the framework was applied to measure the chain digitisation level - in both organisational and technical respects - of 24 Dutch retail branches. The results show that, as of 2007 , the interorganisational chains within the Dutch retail sector are generally immature in their organisational and technological levels of chain digitisation. Exceptions are retail chains within the perfume, tobacco, clothing, books, and furniture branches that show moderate levels of chain digitisation. It appears hard to discover specific patterns underlying these maturity differences between the 24 retail branches. Basic differences between food and non-food, or between supply- and demanddriven branches, appear not be systematically related to the level of chain digitisation. Hence, alternative explanations need to be explored. These might be expected from conditions like the length and diversity of the supply chain, regulatory requirements, branch culture or traditions. These conditions might have interaction effects on the maturity of chain digitisation. For instance, new laws on ingredient track and tracing in the food sector put pressure on the sharing of information throughout the chain (Ménard \& Klein, 2004). As a result parties are enforced to mutually adapt their IT systems and establish a body that governs the matter of chain digitisation within the branch.

The model and data we present in this paper can be used as a basis for further research. As a follow-up to the data we have now collected through branch organisations, it will be interesting to interview representatives of all organisations that build a particular interorganisational chain. In this way, how chain actors differ in their chain digitisation ambitions and perceptions can be explored (cf. Harland, 1996). This undertaking is of course extensive, but would be rewarding in terms of debunking the actual chain connections and locating specific chances and barriers.

With regard to our framework, an interesting extension would be the relaxation of the (implicit) assumption that 'the higher the (chain digitisation) maturity level, the better'. At present, it remains unclear whether this is truly optimal for every chain - especially in the retail sector, including its many SMEs. It might be appropriate to apply a contingency approach and explore the situational factors of our maturity dimensions. This means that it is not assumed that a higher chain digitisation maturity level is always better; it might be 'locally optimal', that is, sufficient for a certain branch. It is interesting to view the maturity models as typologies: they describe the different phases in which a chain can subsist, but do not indicate whether one phase is better than another.

Related to this, it is possible to relax the assumption behind the alignment thesis that organisational maturity preferably coincides with a similar level of technological maturity. For instance, organisations at a certain organisational level of chain collaboration can share the necessary information through a joint information system to which all parties have access. At the same time however, this chain can just as well be supported through a recurrent physical gathering of (representatives of) all parties. In the same vein, there can be a full operational chain information system, but no or only a small amount of parties willing to share their information because the standard for exchanging product specifications is not accepted by all parties in the chain. In all cases, whether maturity levelling as a form of alignment is required will be dependent on the situation. Further research can concentrate on this point of situationality, that is, what kind of chain digitisation is suitable for which condition. 
Finally, an extension of this study is to apply the framework to larger enterprises, other sectors and branches, as well in other countries. Especially the non-profit sector springs to mind, for instance healthcare and governmental organisations. Also, a longitudinal research that follows the chain digitisation development of certain branches will contribute or lead to extended insights.

\section{Implications}

Given the fact that the framework is proven to be applicable for measurement and benchmarking on the level of interorganisational chains, it can also be used to support different branches in their ambition to improve their level of chain digitisation. First of all, policy makers and branch organisations can use the framework as a measurement tool to determine their current level of chain digitisation. Secondly, they can think of a roadmap for chains within their branch that can help to increase their degree of chain digitisation. This matches the goals of both European and national governments that increasingly focus on stimulating the adoption of ICT by small and medium-sized enterprises (SMEs). Since SMEs statistically lag behind large firms in IT adoption and use because of their limited resources, creating chain digitisation projects can support them in collectively overcoming these barriers (cf. European Commission, 2002; Renner et al., 2008). Moreover, this research shows that also small organisations should focus on both technological and organisational aspects in adopting these technologies. Branches can learn from each other in this respect. For instance, branches that are relatively mature in the technological aspects of chain digitisation can learn from branches that are more advanced in organisational cooperation, and vice versa. By finding similarities in their chain characteristics, and comparing their technological (ICT) and organisational initiatives, branches can improve their level of chain digitisation mutually and in parallel. To actually execute a branch-specific roadmap towards mature chain digitisation, that projects the 'to be' situation, is a matter of tailoring and of further research. The maturity levels as defined by our framework and indicators can be a useful support in this. Basically, it helps supply chain partners and interorganisational bodies to initiate specific projects for chain collaboration, chain digitisation and joint investments.

\section{Acknowledgement}

The authors would like to thank Jan Grijpink and Jeroen Segers for their comments on preliminary versions of our framework, and the two anonymous reviewers for their suggestions to improve the manuscript.

\section{References}

Alvarado, U. Y. and Kotzab, H. (2001), "Supply chain management: The integration of logistics in marketing", Industrial Marketing Management, Vol. 30 No. 2, pp. 183-198.

Aryee, G., Naim, M. M. and Lalwani, C. (2008), "Supply chain integration using a maturity scale", Journal of Manufacturing Technology Management, Vol. 19 No. 5, pp. 559-575.

Barrett, S. and Konsynski, B. (1982), "Inter-organization information sharing systems", MIS Quarterly, Vol. 6, pp. 93-105.

Batenburg, R. and Versendaal, J. (2008), "Maturity matters: Performance determinants of the procurement business function", in Golden, W., Acton, T., Conbuy, K., Van der Heijden, H. and Tuuainen, V. (Eds.) 16th European Conference on Information 
Systems (ECIS), Galway, Ireland.

Chan, Y. E. and Reich, B. H. (2007), "IT alignment: An annotated bibliography", Journal of Information Technology, Vol. 22, pp. 316-396.

Clark, T. and Jones, R. (1999), "Organisational interoperability maturity model for C2", Command and Control Research and Technology Symposium, Newport, Rhode Island.

Daft, R. L. (2001), Organizational theory and design, South-Western Educational Publishing, Cincinnati, Ohio.

European Commission (2002), Communication from the commission: E-Europe 2005 action plan, Office for Official Publications of the European Communities, Luxembourg.

European Commission (2008), The European e-business report 2008: The impact of ICT and e-business on firms, sectors and the economy, Office for Official Publications of the European Communities, Luxembourg.

Folinas, D., Manthou, V., Sigala, M. and Vlachopoulou, M. (2004), "E-volution of a supply chain: Cases and best practices", Internet Research: Electronic Networking Applications and Policy, Vol. 14 No. 4, pp. 274-283.

Frohlich, M. T. and Westbrook, R. (2001), "Arcs of integration: An international study of supply chain strategies", Journal of Operations Management, Vol. 19, pp. 185-200.

Gottschalk, P. (2009), "Maturity levels for interoperability in digital government", Government Information Quarterly, Vol. 26 No. 1, pp. 75-81.

Grijpink, J. H. A. M. (1999), "Chain-computerisation for interorganisational public policy implementation: A new approach to developing non-intrusive information infrastructures", Information Infrastructure and Policy, Vol. 6 No. 2, pp. 81-93.

Handfield, R. B. and Straight, S. L. (2004), "How mature is your supply chain? The SCRD capability maturity model", 89th Annual International Supply Management Conference, Philadelphia, Pennsylvania.

Harland, C. M. (1996), "Supply chain management: Relationships, chains and networks", British Journal of Management, Vol. 7 Special Issue, pp. S63-S80.

Henderson, J. C. and Venkatraman, N. (1993), "Strategic alignment: Leveraging information technology for transforming organizations", IBM Systems Journal, Vol. 32 No. 1, pp. 416.

Jacsó, P. (2008), "Google Scholar revisited", Online Information Review, Vol. 32 No. 1, pp. 102-114.

Kalakota, R. and Robinson, M. (2001), E-business 2.0: Roadmap for success, Addison-Wesley Longman, Boston, Massachusetts.

Kärkkäinen, M. (2003), "Increasing efficiency in the supply chain for short shelf life goods using RFID tagging", International Journal of Retail \& Distribution Management, Vol. 31 No. 10 , pp. $529-536$.

Lockamy, A. and McCormack, K. (2004), "The development of a supply chain management process maturity model using the concepts of business process orientation", Supply 
Chain Management: An International Journal, Vol. 9 No. 4, pp. 272-278.

Luftman, J. and Kempaiah, R. (2007), "An update on business-IT alignment: "A line" has been drawn", MIS Quarterly Executive, Vol. 6 No. 3, pp. 165-177.

McCormack, K., Bronzo Ladeira, M. and Valadares de Oliveira, M. P. (2008), "Supply chain maturity and performance in Brazil", Supply Chain Management: An International Journal, Vol. 13 No. 4, pp. 272-282.

McDougall, K., Rajabifard, A. and Williamson, I. (2005), "Understanding the motivations and capacity for SDI development from the local level", From Pharaohs to Geoinformatics: FIG Working Week 2005 and GSDI-8, Cairo, Egypt.

McLaren, T. (2006), "A measurement model for web-enabled supply chain integration", 19th Bled eConference eValues, Bled, Slovenia.

Ménard, C. and Klein, P. G. (2004), "Organizational Issues in the Agrifood Sector: Toward a Comparative Approach", American Journal of Agricultural Economics, Vol. 86 No. 3, pp. 750-755.

Meyer, B., Choppy, C., Staunstrup, J. and Van Leeuwen, J. (2009), "Research evaluation for computer science", Communications of the ACM, Vol. 52 No. 4, p. 31-34.

Morrell, M. and Ezingeard, J.-N. (2002), "Revisiting adoption factors of inter-organisational information systems in SMEs", Logistics Information Management, Vol. 15 No. 1, pp. 46-57.

Paulk, M. C., Weber, C. V., Curtis, B. and Chrissis, M. B. (1995), The capability maturity model: Guidelines for improving the software process, Addison-Wesley, Reading, Massachusetts.

Poirier, C. C. and Bauer, M. J. (2000), E-supply chain: Using the internet to revolutionize your business: How market leaders focus their entire organization on driving value to customers, Berrett-Koehler Publishers, San Francisco, California.

Prananto, A., McKay, J. and Marshall, P. (2003), "A study of the progression of e-business maturity in Australian SMEs: Some evidence of the applicability of the stages of growth for e-business model", 7th Pacific Asia Conference on Information Systems (PACIS), Adelaide, South Australia, pp. 68-80.

Renner, T., Vetter, M., Scheiding, F., Remotti, L. A. and Cavallini, S. (2008), Ebusiness guide for SMEs: Ebusiness software and services in the European market, Fraunhofer IAO \& FORMIT, Stuttgart.

Schoenfeldt, T. I. (2008), A practical application of supply chain management principles, American Society for Quality Press, Milwaukee, Wisconsin.

Scott Morton, M. S. (Ed.) (1991), The corporation of the 1990s: Information technology and organizational transformation, Oxford University Press.

Seidmann, A. and Sundararajan, A. (1998), "Sharing logistics information across organizations: Technology, competition and contracting", in Kemerer, C. F. (Ed.) Information Technology and Industrial Competitiveness: How IT Shapes Competition, Kluwer Academic Publishers, Boston, Massachusetts, pp. 107-136. 
Shah, R., Goldstein, S. M. and Ward, P. T. (2002), "Aligning supply chain management characteristics and interorganizational information system types: An exploratory study", IEEE Transactions on Engineering Management, Vol. 49 No. 3, pp. 282-292.

Skjoett-Larsen, T., Thernøe, C. and Andresen, C. (2003), "Supply chain collaboration: Theoretical perspectives and empirical evidence", International Journal of Physical Distribution \& Logistics Management, Vol. 33 No. 6, pp. 531-549.

Statistics Netherlands (2006), The digital economy 2005, Statistics Netherlands, Voorburg/Heerlen.

Turban, E., King, D., Viehland, D. and Lee, J. K. (2004), Electronic commerce 2004: A managerial perspective, Pearson-Prentice Hall, Upper Saddle River, New Jersey.

Turban, E., McLean, E. R. and Wetherbe, J. C. (2001), Information technology for management: Making connections for strategic advantage, Wiley, New York.

Tyndall, G., Gopal, C., Partsch, W. and Kamauff, J. (1998), Supercharging supply chains: New ways to increase value through global operational excellence, John Wiley \& Sons, New York.

Vaaland, T. I. and Heide, M. (2007), "Can the SME survive the supply chain challenges?", Supply Chain Management: An International Journal, Vol. 12 No. 1, pp. 20-31.

Vaidyanathan, K. and Howell, G. (2007), "Construction supply chain maturity model Conceptual framework", 15th Annual Conference of the International Group for Lean Construction (IGLC-15), East Lansing, Michigan, pp. 170-180.

Van Beers, C. and Bouwman, H. (2007), "Travel agents and ICT technologies", in Wolters, T. (Ed.) Measuring the New Economy: Statistics between Hard-Boiled Indicators and Intangible Phenomena, Elsevier, Amsterdam, The Netherlands, pp. 127-142.

Vieira, J., Yoshizaki, H. and Ho, L. (2009), "Collaboration intensity in the Brazilian supermarket retail chain", Supply Chain Management: An International Journal, Vol. 14 No. 1, pp. 11-21.

Wagner, B. A., Fillis, I. and Johansson, U. (2003), "E-business and e-supply strategy in small and medium sized businesses (SMEs)", Supply Chain Management: An International Journal, Vol. 8 No. 4, pp. 343-354.

Wang, Y. C. W., Chang, C.-W. and Heng, M. S. H. (2004), "The levels of information technology adoption, business network, and a strategic position model for evaluating supply chain integration", Journal of Electronic Commerce Research, Vol. 5 No. 2, pp. 85-98.

Williamson, E. A. (2007), "An evaluation of inter-organisational information systems development on business partnership relations", International Journal of Business Science and Applied Management, Vol. 2 No. 3, pp. 36-50.

Zhu, K. and Kraemer, K. L. (2002), "E-commerce metrics for net-enhanced organizations: Assessing the value of e-commerce to firm performance in the manufacturing sector", Information Systems Research, Vol. 13 No. 3, pp. 275-295.

Zhu, K., Kraemer, K. L., Gurbaxani, V. and Xu, S. (2006), "Migration to open-standard interorganizational systems: Network effects, switching costs, and path dependency", 
MIS Quarterly, Vol. 30 Special Issue, pp. 515-539.

\section{About the authors}

First author

- $\quad$ Full name: Marijn G.A. Plomp

- Affiliation: Utrecht University, Information and Computing Sciences, Utrecht, The Netherlands; Dialogic innovation \& interaction, Utrecht, The Netherlands

- E-mail address: m.g.a.plomp[AT]cs.uu.nl

- Full international contact details: Padualaan 14, P.O. Box 80115, 3508 TC Utrecht, The Netherlands, +31(0)302535433

- Brief professional biography: Marijn Plomp (1984) holds an MSc in Information Science from Utrecht University and currently works as a PhD Researcher in the group Organisation and Information of the same university. His research focuses on the technological and organisational determinants of chain digitisation. He also has a position as researcher/consultant at Dialogic innovation \& interaction in Utrecht, The Netherlands. Marijn is the corresponding author and can be contacted at m.g.a.plomp[AT]cs.uu.nl.

Second author

- Full name: Ronald S. Batenburg

- Affiliation: Utrecht University, Information and Computing Sciences, Utrecht, The Netherlands

- E-mail address: r.s.batenburg[AT]cs.uu.nl

- Full international contact details: Padualaan 14, P.O. Box 80115, 3508 TC Utrecht, The Netherlands, +31(0)30 2536454

- Brief professional biography: Dr. Ronald Batenburg (1964) obtained his masters at Utrecht University and his PhD in 1991 at Groningen University based on the dissertation "Automation at Work. The Influence of Automation on the Job Structure of Organisations". Since then, he worked at the Universities of Utrecht, Tilburg and Nijmegen as assistant professor in organisational sociology, strategic policy making and HRM. Since 2000 he is associate professor at Utrecht University, Department of Information and Computing Sciences. His research interest and publications are in the field of business-IT alignment, implementation of ERP-systems, teleworking and CRM, as well as inter-organisational issues as the extended enterprise and e-procurement. 